\title{
RESIDENCE LIFE AND LEADERSHIP DEVELOPMENT
}

Philomena Dadzie, Banking and Finance Department at the University of Professional Studies Accra, Ghana

\author{
dx.doi.org/10.18374/JIBE-20-1.5
}

\begin{abstract}
Leadership development in students is an important outcome for students in higher education. Relatively few researchers have studied leadership development of students and residence life. This paper looks at literature covering different benefits to students in residence hall, with focus in the area of leadership development. There are many factors contributing to the students' success in leadership development in residence halls, including the compelling force to influence others in their actions and behaviors, and the opportunity for students to participate in students' housing governance. The main findings is that while there may be varied views about students who choose to be in residence halls, there is a positive influence on students in developing leadership skills.
\end{abstract}

Keywords: Residence life, students, leadership development 